\title{
Anticristo: o retardamento da parusia e seus reflexos no deuteropaulinismo (2Ts 2,1-12): uma excursão ao contexto macabaico (Dn 9,20-27)
}

\author{
Orientador: Prof. Waldecir Gonzaga \\ Pesquisador: Luan Ferreira do Nascimento \\ Fonte: $\mathrm{CNPq}$
}

\section{Introdução}

A primeira fase desta pesquisa tem por objetivo apresentar a relação entre o judaísmo da primeira metade do séc. II a.C. e o cristianismo nascente da segunda metade do séc. I d.C. A apocalíptica judaica, em sua periodização da história, demarca de forma indefectível a mentalidade escatológica da escola paulina (Dn 9,26; 2Ts 2,8). Sendo assim, o redator deuteropaulino fundamenta todo o seu discurso parenético, tomando por base reminiscente a apocalíptica histórica do livro de Daniel.

É na efervescência de cunho epistolar que o redator instalará o seu "programa escatológico", na tensão dialética entre o "já" e o "ainda não" da parusia, fazendo ressurgir uma figura oriental que permanecerá como um véu a ser desvendado pelo imaginário de "crentes" e "descrentes": o Anticristo.

\section{Objetivos}

Contextualizar e identificar, a partir da análise da temática do renascimento do Anticristo na segunda epístola aos Tessalonicenses, o ambiente social, étnico, geográfico e o desenvolvimento da religiosidade dos Tessalonicenses. O mesmo será feito em Daniel, a fim de analisar o desenvolvimento da religiosidade dos hassideus. Analisar a base do Antigo Testamento. Checar as origens das expressões "dia do Senhor", "homem ímpio", "filho da perdi- 
ção", "o adversário" e "apostasia" na perícope neotestamentária. Checar as origens das expressões "setenta semanas", "sete semanas", "sessenta e duas semanas", "uma semana", "meia semana", "Príncipe Ungido" e "desolação" perícope veterotestamentária. E, por último, compreender o renascimento do Anticristo a partir de 2Ts 2,1-12. 